International Journal of Public Finance
E-ISSN: $2548-0499 \quad$ DOI: $10.30927 /$ ijpf.327827
Vol./Cilt: 2 | Issue/Sayı: 1 | (2017), pp. $109-123$
journal homepage: http://dergipark.gov.tr/ijpf

\title{
Uluslararası Sermaye Yatırımlarının Vergilendirilmesinde Tarafsızlık İlkesi
}

\author{
Tax Neutrality on International Capital Investments
}

\author{
Gizem KAPUCU ${ }^{1}$
}

\section{ARTICLE INFO \\ Received: 11.07.2017 \\ Received in revised \\ form: 12.09.2017 \\ Accepted: 14.09.2017 \\ Available online: \\ 15.09.2017 \\ JEL classification: \\ F21, K34 \\ Keywords: \\ Tax Neutrality, Capital \\ Export Neutrality, \\ Capital Import \\ Neutrality}

\begin{abstract}
A B S T R A C T
The tax policies which states follow with regard to developing technology and capital investments with raising mobility due to globalism are need to be discussed in its legal basis. The principle of tax neutrality has the aim of being legal foundation for these policies. According to this, the neutrality principle in taxation of international capital investments is provided with two measures, namely; not effecting the investment decision and not discriminate between investments. In this paper, initially focused on the conceptual framework and the foundations of the tax neutrality principle and later capital export neutrality and capital import neutrality are considered and explained with regard to international capital movements. Moreover, conformity and diversion to the principle of the current situation and regulations in OECD, EU and Turkey are examined.
\end{abstract}

\section{MAKALE BILGISi}

Alındı: 11.07.2017

Gözden geçirilmiş

alındı: 12.09 .2017

Kabul: 14.09 .2017

Yayın: 15.09.2017

\section{JEL Kodu:}

F21, K34

\section{Anahtar Kelimeler: \\ Vergi Tarafsızı̆̆ı \\ Illkesi, Sermaye İhraç}

\begin{abstract}
Ö Z E T
Gelişen teknoloji ve küreselleşme sonucu hareketliliği artan sermaye yatırımları bakımından devletlerin izlediği vergi politikaları, hukuki bir temelde tartışılmaya muhtaçtır. Vergi tarafsızlığı ilkesi bu politikalara hukuki bir zemin sağlama amacı taşır. Bu ilkeye göre uluslararası sermaye yatırımlarının vergilendirmesinde tarafsızlık ilkesi; yatırım kararını etkilememe ve yatırımlar arasında ayrımcılık yapmama şeklinde iki ölçütle sağlanır.

Çalışmada öncelikle vergi tarafsızlığı ilkesinin kavramsal çerçevesi ve temelleri üzerine odaklanılmış, ardından uluslararası sermaye hareketleri bakımından sermaye ihraç tarafsızlığı ve sermaye ithal tarafsızlığı ele alınıp açıklanmıştır. Çalışmada ayrıca $O E C D, A B$ ve Türkiye bakımından mevcut
\end{abstract}

\footnotetext{
${ }^{1}$ Araş. Gör., Marmara Üniversitesi Hukuk Fakültesi Mali Hukuk Anabilim Dalı, gizem.kapucu@marmara.edu.tr
} 
Tarafsızlığı, Sermaye Ithal Tarafsızlığı durum ve düzenlemeler ilkeye uyum ve ilkeden sapma durumları incelenmiştir.

\section{Giriş}

Vergilendirmede tarafsızlık (tax neutrality) ilkesi en genel tanımıyla, vergi sisteminin; mükellefin kararı üzerinde etkisinin minimum seviyede tutulması ve her mükellef için aynı şekilde oluşturularak uygulanmasıdır. Mükellefin kararı üzerinde minimum etkisinin olması, seçim özgürlüğü teorisi ile; her mükellef için aynı şekilde uygulanması ise eşitlik ilkesi ile yakından ilişkilidir. Bu nedenle, eşitliği bozucu ve mükellefin kararları üzerinde etki yaratıcı vergi uygulamaları, tarafsızlık ilkesinden sapma oluştururlar.

Küreselleşme sonucu hareketlenen ve vergiye duyarlı hale gelen uluslararası sermaye yatırımları bakımından vergi sonrası getiri oranları farklılaştığında (Furman, 2008:9) bu ilke daha önemli bir hal alır. Bunun nedeni böyle bir durumda mükellefin sermayesi için yatırım yerini ve türünü belirlerken vergiyi bir etken olarak düşünmesidir. Devletler yatırımcıları etkilemek için vergi sistemlerini bir faktör olarak kullanma eğilimi içindedir. Bu eğilime hukuki bir sınır çizilmesi ve devletlerin bu sınır içinde kalmasının sağlanması uluslararası vergi hukukunun en önemli konularından birini oluşturur. Günümüzde devletler ekonomik istikrar ve büyüme hedefleri doğrultusunda hareketliliği üst seviyede olan sermayeye büyük önem vermektedirler. $\mathrm{Bu}$ bağlamda yabancı sermayeyi çekmek kadar, yerli sermayeyi elde tutmak da devletlerin hedefi haline gelmektedir. Bu durumun hukuk bilimini ilgilendiren yönü ise, birinci olarak; uygulamaların ayrımcılık yasağı kapsamında değerlendirilip değerlendirilmeyeceği noktasında kendini gösterir. Hukukun konuya dair bir diğer ilgi noktası ise, devletlerin ticari hayata keyfi müdahalesinin ve ayrımcılık oluşturan uygulamalarının sınırını belirlemektir. Günümüzde devletlerin egemenlik yetkileri sınırsız kabul edilmez. Devletler çoğu zaman bu kabülü kendilerini anlaşmalar yoluyla sınırlayarak ve bu sınırı kayıt altına alarak ortaya koyarlar. Bu bakımdan devletlerin yükümlülüğü salt bir ulusal hukuk sistemine bağlılık değil; uluslararası hukuk ilkelerine ve taraf olunan anlaşmalara da uygun davranma yükümlülüğü olarak ortaya çıkar. Devletler vergi aracılığıyla uluslararası sermaye hareketlerine müdahalede bulunduklarında, bu müdahalenin sınırı da gerek iç hukuk sistemi ile gerekse uluslararası hukukun ilkeleri ve taraf olunan anlaşmalarla belirlenir. İşte bu sınırın belirlenmesinde kullanılacak ölçütlerin tespiti uluslararası vergi hukukunun konularından ve amaçlarından birini oluşturur.

Çalışmanın amacı, mükellefin seçim özgürlüğü ışığında ve eşitlik ilkesi çerçevesinde vergi sistemlerinin sermaye yatırımları üzerindeki etkisinin ve devletlerin ticari hayata müdahale etme sınırının incelenmesidir. Böyle bir incelemenin uluslararası sermaye hareketleri bakımından sermaye ihraç tarafsızlığı ve sermaye ithal tarafsızı̆̆ı olarak iki görünümü ortaya çıkar. Çalışmanın diğer bölümünde ise ilkenin hukuk düzenlemeleri karşısındaki konumu; ilkeye uyum ve ilkeden sapmalar ele 
alınacak ve bu çerçevede OECD (Ekonomik İşbirliği ve Kalkınma Örgütü), Avrupa Birliği $(A B)$ ve Türkiye bakımından mevcut durum, hukuki düzenlemeler ve yaklaşımlar irdelenecektir. İlkeden sapma durumlarının haklı nedeni ve düzenlemelerin bu amaca uygunluğu da çalışmada tartışılacak olan konulardandır. Bu tartışmanın nihai hedefi ise, uluslararası sermaye hareketliliği üzerinde vergi sistemlerinin etkisinin hukuken kabul edilebilir olabilmesi için nasıl bir hukuki sınır çizilmesi gerektiğine dair bir fikir üretmektir. Bunun gerçekleşebilmesi için ise ilk yapılması gereken tarafsızlık ilkesinden sapma durumlarının haklı nedenlerini araştırarak, korumanın ölçülü olup olmadığının tespit edilmesidir.

\section{Sermaye Hareketlerinin Vergilendirmesinde Tarafsızlık Illkesinin Anlamı ve Alt ilkeleri}

\section{1. İlkenin Anlamı}

Uluslararası sermaye yatırımlarının vergilendirmesinde tarafsızlık ilkesi; yatırım kararını etkilememe ve yatırımlar arasında ayrımcılık yapmama şeklinde iki ölçütle sağlanabilir. Bu ölçütler ise i) seçim özgürlüğü teorisi ve ii) eşitlik ilkesi çerçevesinde değerlendirme yapmayı gerekli kılar.

Seçim özgürlüğü teorisi; yatırım kararı üzerinde etkisiz, başka bir deyişle nötr bir vergi sistemi oluşturulmasını öngörür (Bracewell-Milnes, 1988; 1). Bunu sağlayacak ölçütlerden biri yatırım yapılan ülke ile mukim olunan ülke arasındaki vergi sistemlerinin, -asgari seviyede vergi oranlarının- uyumlu olmasıdır. Vergi oranlarının farklılaştığı durumlarda ise ülkeler iki taraflı anlaşmalar veya kendi kanunlarında yapacakları düzenlemeler ile oluşması muhtemel uyumsuzları gidererek sermaye hareketliliğinin vergilendirilmesinde nötr bir sistem oluşturabilirler.

Seçim özgürlüğü kapsamında tarafsız bir vergi sistemi oluşturulabilmesi için bir diğer ölçüt ise, Adam Smith'in uygunluk prensibi olarak karşımıza çıkan, vergi zamanının mükellefe en uygun zaman olarak belirlenmesidir (Smith, 2014: 928-929). $\mathrm{Bu}$ ölçüt uluslararası sermaye yatırımlarının vergilendirilmesine uygulandığında şu sonuç ortaya çıkar: yatırıma ev sahipliği yapan ülke ve yatırımcının mukimi olduğu ülkenin vergilendirme zamanı mükellefe en uygun zaman -aynı zaman- olmalıdır. Buna göre, ev sahibi ülke yabancı yatırımcıyı gelir elde ettiğinde değil de, bu geliri ülkesine götürdüğü zaman (gelir ülkeden çıktığında); mukim olunan ülke ise, elde edilen gelir ülkeye girdiği zaman vergilendirmelidir (Abbasov, 2005: 91). Uygunluk prensibi ve ülkeler arası uyum; mükellefin karar alma sürecine etkinin nötrleşmesini sağlayacak ölçütlerdir.

Tarafsızlık ilkesi, vergi sistemlerinin her mükellefe aynı şekilde uygulanması gerektiği şeklinde ortaya konduğunda da eşitliğin bir alt ilkesi olarak değerlendirilir. Bu bağlamda tarafsız bir vergi sistemi oluşturulması için önerilecek olan ölçüt -asgari seviyede- ayrımcılık yasağı olarak karşımıza çıkar. Uluslararası yatırımlar arasında ayrımcılığa yol açan ve eşitlik ilkesini zedeleyen 4 durum vardır: (i) sermaye girişini 
kısıtlama (inbound restrictions) (ii) sermaye çıkışını kısıtlama (outbound restrictions) (iii) yerel yatırımcının yabancı yatırımını teşvik etme (outbound preferences) (iv) yabancı yatırımcıyı yerel yatırımcıya göre destekleme (inbound preferences) (Warren, 2001: 150). Daha genel bir gruplandırma yapmak gerekirse bu ayrımcılık türlerini kısıtlama yoluyla yapılan ayrımcılık (i, ii) ve teşvik yoluyla yapılan ayrımcılık (iii, iv) olarak 2 ana grupta ele almak da mümkündür. Bu noktada sermaye hareketliliği üzerinde etkisi olan vergi uygulamalarından; sermaye kontrolü ve devlet yardımları üzerinde durmak gerekir. Sermaye kontrolleri, kısıtlamalar yoluyla ayrımcılık oluştururken; devlet yardımları da teşvik yoluyla ayrımcılık oluşturan uygulamalardandır.

Sermaye kontrolleri, ülkelerin piyasalarından çıkan veya piyasalarına giren sermayeyi kontrol etmek için kullanabileceği işlem vergileri, diğer sınırlar veya tamamen yasaklama şeklinde kendini gösteren düzenlemeler ve/veya kısıtlamalardır. Konumuz bakımından sermaye hareketlerine getirilen vergisel kısıtlamalara odaklanmak gerekir. Bu konuyla bağlantılı bir vergi sistemi önerisi, uluslararası menkul sermayeyi spekülatif olarak gören Keynes tarafından, bu sermaye üzerine konulacak bir vergi ile uzun dönemli istikrar sağlanacağı savıyla ortaya atılmıştır (http://www.ab.gov.tr/files/EMPB/finansal_islem_vergisi_empb_print_version.pdf, Erişim Tarihi: 31.03.2017). Ardından James Tobin, döviz alım satımları üzerine bir vergi konulması fikrini ortaya atmıştır (Tobin, 1994). Tobin bu suretle kurlarda bir istikrar sağlamayı hedeflemesinin yanı sıra, elde edilecek gelirin küresel kalkınma için oluşturulacak bir fona aktarılmasını da önermiştir (http://www.ab.gov.tr/files/EMPB/ finansal_islem_vergisi_empb_print_version.pdf, Erişim Tarihi: 31.03.2017). Günümüzde de gerek AB düzeyinde ${ }^{2}$ (bkz. EC COM (2013) 71 final) gerek IMF nezdinde (bkz. a Fair and Substantial Contribution by the Financial Sector Final Report for The G$20,2010)$ konu güncel şekilde tartışılmaya devam etmektedir. Tartışmaların odağında finans sektöründe oluşan ekonomik krizleri çözmek için bir fon oluşturma hedefinin ağır bastığı görülür.

Yerel sermayenin yurtdışına çıkışını önlemek adına, bir sermaye kontrolü aracı olarak "çıkış vergisi (exit tax) uygulaması" da gündeme gelir. Çıkış vergisi birazdan daha ayrıntılı açıklanacağı üzere Avrupa Birliği düzenlemelerinde de karşımıza çıkmaktadır. Bu vergi türü, yerleşik bir mükellefin (gerçek veya tüzel kişinin) yabancı ülkeye göçü veya varlıklarını yabancı ülkeye transfer etmesi durumunda, çıkış yapılan devletin kendi topraklarında yaratılan sermaye kazançlarının ekonomik değerini, çıkış anında serbest piyasa üzerinde henüz kazanılmamış olsa bile vergiye tabi tutabilmektedir. Bu suretle mükellefin yurtdışına sermaye çıkarmasına bir sınırlama getirilmiş olur.

\footnotetext{
22016 sonlarında Avrupa Komisyonu'nun ekonomik ve parasal işlerden sorumlu üyesi Pierre Moscovici, finansal işlem vergisi için (financial transaction tax-FTT) çok önemli ilerlemeler kaydedildiğini söylemiştir. Bu konuda bir taslak metin üzerinde çalışıldığını belirtmiştir (http://www.cityam.com/251202/eu-financial-transaction-tax-unveiled-year, Erişim Tarihi: 12.04.2017). Avrupa düzeyinde bir finansal işlem vergisine destek veren ülkeler ise şunlardır: Almanya, Avusturya, Belçika, Estonya, Fransa, İspanya, İtalya, Postekiz, Slovakya ve Slovenya.
} 
Sermaye üzerinde ayrımcılık oluşturabilecek diğer uygulama ise vergi teşvikleridir. Vergi teşvikleri, 20. yüzyılda küreselleşme ile önem kazanmıştır; 21. yüzyılda ise bu durum önemini daha da artırmıştır. Serbest piyasa ekonomisinin kısıtlamaları kaldırma yönündeki eğilimi nedeniyle, teşvikler devletlerin en önemli piyasaya müdahale araçlarından biri haline gelmiştir (Eser, 2011:1).

Anılan ayrımcı uygulama ve düzenlemelere karşı 2 ilke geliştirilmiştir. Bunlar sermaye ihraç tarafsızlığı ve sermaye ithal tarafsızlığıdır.

\subsection{Sermaye Hareketliliğinin Vergilendirilmesinde Tarafsızlık İlkesinin Alt İkeleri}

\subsubsection{Sermaye ihraç Tarafsızlığı}

Sermaye ihraç tarafsızlığı, bir ülkede yerleşik kişinin nerede yatırım yaparsa yapsın, aynı şekilde vergilendirilmesini savunur. Bu nedenle ikamet ilkesine göre vergilendirilmeyi esas alır (Griffith vd. 2010: 926) ve yurtiçinden elde edilen gelir ile yurtdışından elde edilen gelire aynı muameleyi yapar. Bu şekilde vergi sistemleri göz önünde bulundurulmaksızın, sermayenin en etkin olarak kullanılacağı yere tahsis edilmesini amaçlar (Weisbach, 2015: 637). Bu ilke yerli yatırımcının yabancı yatırımı ile yerli yatırımı arasında ayrım yapılmamasını sonuçlar. Örnekle açıklamak gerekirse, Türkiye'de \% 20 oranında uygulanan kurumlar vergisine karşılık, Amerika Birleşik Devletleri'nin \% 15 oranında, Avrupa Birliği ülkelerinin ise \% 30 oranında kurumlar vergisi öngördüğünü varsayalım. Böyle bir vergi sisteminde, Türkiye'den çıkacak olan bir sermaye akışı bakımından sermaye ihraç tarafsızlığının sağlanabilmesi için, Türk yatırımcıların; $A B^{\prime}$ de yapacağı yatırım ile $A B D^{\prime}$ de yapacakları yatırımın ve sermaye çıkışının olmadığı bir durumda Türkiye'de yapacakları yatırımın aynı şekilde vergilendirilmesi gerekir. Ülkelerin vergi oranları farklılaştığında vergi sonrası getiri de farklılaşacağından, tarafsızlığın sağlanabilmesi için; yatırımcı ikamet ilkesine göre örneğimizde Türkiye'de uygulanan orandan- vergilendirildiğinde her durumda \%20'lik bir yük ile karşı karşıya kalacaktır. Yatırım yapılan ülkenin de vergilendirme yapması durumunda ise, indirim ya da istisna yönteminin uygulanması gerekir. Böylece vergi sonrası getiriler eşitlenerek, sermaye hareketliliği üzerinde verginin etkisi ortadan kaldırılmış olur. Sermaye ihraç tarafsızlığının arkasındaki normatif amaç, yatırımcının yatırım yapacağı yer konusunda seçim yaparken vergileri değil, ticari amaçları göz önünde bulundurmasıdır (Mason, 2010: 6). Nitekim yukarıda verdiğimiz örnekte 3 farklı ülke ve 3 farklı vergi oranı söz konusu olduğunda;

- yatırımcı sermayesini ihraç edip etmeme konusunda ve

- ihraç edecek ise hangi ülkeye ihraç edeceği konusunda;

vergi sistemlerini göz önünde bulundurmadan bir tercih yaparsa sermaye ihraç tarafsızlığı sağlanmış olur. Böylece yatırımcı vergi dışı faktörleri göz önünde bulunduracak ve sermaye, en etkin kullanıldığı yere tahsis edilmiş olacaktır. Sermaye ihraç tarafsızlığına getirilebilecek eleştirilerden birisi de esasında budur. Vergi dışı faktörlerin sermayeyi çekmeye başlaması, doğrudan yatırımlar bakımından bazı riskler 
içerir. Doğrudan yatırımlarda işçi maliyeti gibi birtakım sosyal konuların yatırım kararı


finans sektörü bakımından böyle bir risk söz konusu olmadığından, bu sektör için sermaye ihraç tarafsızlığının sağlanmasına yönelik olarak bu yönde bir eleştiri getirmek mümkün değildir.

Sermaye ihraç tarafsızlığı ilkesine göre, sermaye ihracına konulacak kısıtlamalar ve yine sermaye ihracı için yapılacak olan teşvikler ayrımcılık yaratarak, bu ilkeden sapma durumları meydana getirir. Sermaye ihracına konulacak kısıtlamalar için güncel bir örnek olarak çıkış vergisi uygulaması gösterilebilir ${ }^{4}$. Sermaye ihracı teşvikleri için ise yurtdışı iştirak kazançları istisnası örnek olarak verilebilir.

\subsubsection{Sermaye ithal Tarafsızlığı}

Sermaye ithal tarafsızlığı, tüm yatırımların, yatırımcının yerleşim yerine bakılmaksızın, aynı şekilde vergilendirilmesi gerektiğini savunan bir ilkedir. Buna göre, sermayenin kaynak ilkesine göre vergilendirilmesini (Griffith vd. 2010:926) esas alır. Örnek vermek gerekirse Türk yatırımcılarının her bir pazarda $A B$ yatırımcılarıyla aynı oranda vergi ödemelerini şart koşar. Bunun somutlaşmış hali şudur: Avrupa Birliği'ndeki $A B$ ve Türk yatırımcıları \% 30 oranında vergi ödemelidir. Benzer şekilde, sermaye ithal tarafsızlığı Türkiye' de yatırım yapan AB merkezli yatırımcıların, Türkiye'ye \% 20 oranında vergi ödemelerini gerekli kılar. Bu oran, Türk yatırımcıların iç pazarda yapacakları yatırım üzerinden ödedikleri vergi oranı ile aynıdır. Böyle bir vergi sistemi sermaye ithal tarafsızlığını sağlayacaktır.

Sermaye ithal tarafsızlığı yabancı yatırımcı ile yerli yatırımcı arasında ayrımcılığa karşı çıkar. Bu şekilde yatırım tasarrufunda (Weisbach, 2015: 637) ve rekabette etkinlik (Vail, 2011: 180) sağlamayı amaçlar. Bu suretle mukim yatırımcılar, yatırım yaptıkları ülkedeki tüm yatırımcıların aynı şekilde vergilendirilmesi nedeniyle eşit vergi koşullarında rekabet edebilir (OECD Tax Policy Studies: Tax Effects on Foreign Direct Investment - No. 17 Tarih yok).

Bu ilkeye göre, sermaye ithaline konulacak kısıtlamalar ve sermaye ithalini teşvik edecek vergi uygulamaları bu ilkeye aykırılık oluşturur. Sermaye çekmek amacıyla yapılan ve rekabet bozucu nitelikte olan devlet yardımları bu ilkeden sapma durumuna örnek olarak verilebilir. Ayrıca sermaye ihracının kısıtlanmasına yönelik uygulamalar sonucu sermaye yurtiçinde kaldığında, bu durum sermayenin tahsis edileceği kaynağın belirlenmesine de etki eden bir faktör olarak sermaye ithal tarafsızlığından sapma olarak nitelendirilebilir.

\footnotetext{
3 Yazar, işçi haklarının kısıtlı olduğu, grevlerin yasaklandı̆̆ı ya da işlevsiz hale getirildiği, sosyal politikaların zayıf olduğu ülkelerin yatırım için daha elverişli olduğunu belirtmektedir.

${ }^{4}$ Çıkış vergisi ile ilgili detaylı açıklamalar “3.2 AB’nin Yaklaşımı” başlığı altında verilecektir.
} 


\section{Somut Hukuki Düzenlemelerin Vergi Tarafsızlığı İlkesi Karşısında Durumu}

\subsection{Genel Olarak}

Her ülke aynı vergi sitemine sahip olmadığı sürece, sermaye ihraç ve ithal tarafsızlığı ilkelerinin aynı anda sağlanamayacağına ilişkin yaygın bir görüş mevcuttur (Knoll, 2011: 107) ${ }^{5}$. Buna karşın, anılan iki ilkenin bir arada mevcut olup olamayacağına dair tartışmalar; pratikte ayrımcılık yasağı ve/ veya çifte vergilendirmenin hafifletilmesi ile ilgili konularda kendini gösterir (OECD/ TPA, 2003: 13). Bu nedenle ülkeler vergi anlaşmalarında ve uluslararası vergi hukukunun temel düzenlemelerinde sermaye hareketliliğinin vergilendirilmesinde tarafsızlık ilkesini bu kapsamda ele almaktadır.

\subsection{OECD'nin Yaklaşımı}

OECD uygulamasında vergi tarafsızlığı, bir amaç olarak dile getirilir (OECD Tax Policy Studies: Tax Effects on Foreign Direct Investment - No. 17). Gelir ve Servet Üzerinden Alınan Vergilere İlişkin Model Anlaşma (Model Tax Convention on Income and Capital) md. 24 ayrımcılık yasağı (non-discrimination) başlığı altında bu ilkeye normatif bir değer kazandırır. 24. maddenin birinci fıkrasına göre; bir Akit Devletin vatandaşları, diğer Akit Devlette, bu diğer Devletin vatandaşları ile aynı koşullarda, özellikle mukimlik yönünden, ... daha ağır bir vergilemeye ve buna bağlı mükellefiyetlere tabi tutulmayacaklardır." Görüldüğü üzere bu fıkra, uyrukluğa dayalı ayrımcılığa karşı çıkmaktadır; ancak önemle belirtmek gerekir ki yasaklanan ayrımcılık, yabancı yatırımcının sermaye girişini kısıtlama şeklinde ortaya çıkan ayrımcılıktır. Buna karşın yabancı yatırımcının teşvik edilmesi yoluyla ortaya çıkan ayrımcılık, bu maddenin yasağı kapsamında değildir. Maddenin üçüncü fıkrası ise bir Akit Devlet teşebbüsünün diğer Akit Devlette sahip olduğu işyerinin aynı faaliyetleri yürüten teşebbüslerin tabi olduğu vergilemeye göre daha az lehe bir vergilendirmeye tabi tutulmasını yasaklar. Böylece bir teşebbüsün bulunduğu yere dayalı ayrımcılı̆̆ın önlenmesi amaçlanır(GiB, 2014:317, parag.33). Böylece uyrukları ne olursa olsun, bir Akit Devletin diğer Akit Devletteki iş yerine sahip tüm mukimlerini kapsar (GiB, 2014: 317, parag.33).

Belirtmek gerekir ki, 24. madde hükümleri, ayrımcılığın her biçimine değinmez, bazı özel durumları kapsamakla yetinir. Örneğin, teşvikler yoluyla yabancı sermayenin girişinin teşvik edilmesi, OECD Model Anlaşmasında ayrımcılık yasağı olarak değerlendirilmemektedir. Bir diğer örnek olarak; bir devletin kendi mukiminin yurtdışı yatırımlarına yurtiçi yatırımlarına nazaran daha ağır/daha az biçimde vergi yüklemesinin yasak olarak kabul edilmemesi gösterilebilir. Dolayısıyla madde, konusu bakımından oldukça dar bir uygulama alanına sahiptir. Sonuç olarak, yatırımcı üzerinde

\footnotetext{
5 Sermaye ithal tarafsızlığının literatürde kabul edilen iki farklı temeli olduğunu belirten Knoll, temellerden birisinin tasarrufta etkinliğe; diğerinin ise rekabette etkinliğe, başka bir ifadeyle, mülkiyet tarafsızlığına atıf yaptığını belirtir. Bu ikisi arasında oluşacak olan fark, mülkiyet tarafsızlığı temelinde yükselecek olan sermaye ithal tarafsızığı anlayışı ile sermaye ihraç tarafsızlığının aynı anda sağlanabilecek olmasıdır.
} 
etki yaratılmasını tam olarak önleyici bir sistem kurmayan OECD Model Anlaşması, tarafsızlık ilkesini sağlamaya yönelik yeterli işleve sahip değidir. Buna karşın yabancı yatırımcıyı koruyucu hükümler içermesi nedeniyle, sermaye girişinin kısıtlanmasına yönelik ayrımcılık türünü yasaklar. Böylece sermaye ithal tarafsızlığının bir ayağını kısıtlamaları kaldırma - sağlar.

\subsection{AB'nin Yaklaşımı}

Avrupa Birliği, temeli olan dört hareket özgürlüğü (Barnard, 2010:3) anlayışına uygun olarak, 2016 yılına kadar sermaye hareketliliği için konulacak tüm kısıtlamaları kaldırmaya yönelik bir yaklaşım içinde olmuştur. Nitekim 2002 tarihli Avrupa Birliği Antlaşması ve Avrupa Topluluğunu Kuran Antlaşmanın Konsolide Edilmiş Versiyonu md. 56 'da üye devletler ile üçüncü ülkeler arasında sermaye hareketine ilişkin tüm kısıtlamaların yasaklanacağı hükme bağlanmıştır. Buna karşın 2016 yılında yayınlanan AB Vergiden Kaçınma Karşıtı 2016/1164 sayılı Direktif'te çıkış vergilendirmesine (exit taxation) izin veren düzenlemeler vardır. Direktifin giriş bölümünün 5. paragrafında vergiden kaçınmaya karşı bir araç olarak kullanılabileceği belirtilen çıkış vergisi, 10. paragrafta "bir mükellefin sermaye varlıklarını veya maliikametgahını bir Devletin vergilendirme alanından çıkardığı durumlarda, bu Devletin kendi topraklarında yaratılan ekonomik değerin - kazanç henüz gerçekleşmemiş olsa bile vergilendirmesi" olarak ifade edilir. Ayrıca 5. madde hangi durumlarda çıkış vergisinin uygulanacağını düzenler. Bu düzenleme $A B$ üyesi ülkelere, bir şirketin mukimliğinin yüksek vergili bir ülkeden düşük vergili bir ülkeye taşınması gibi durumlarda, şirketlerin yaratmış olduğu ancak henüz realize olmamış gelirleri de vergileme hakkı tanır (Üstün \&Özsoy, http://www.kpmgvergi.com/Blog/Pages/FullBlog.aspx?article=593, Erişim Tarihi: 31.03.2017).

Çıkış vergisi, sermaye ihracına yönelik bir sınırlandırma olmasına rağmen $A B$ Direktifinde bu sınırlama vergiden kaçınmaya karşı kullanılacak bir araç olma ölçütüyle meşrulaştırılmaktadır.

Çıkış vergisi, gayrimaddi varlıklar söz konusu olduğunda daha önemli bir hal alır. Avrupa Komisyonu'nun paketle ilgili basın bildirisinde verilen örnek (http://europa.eu/ rapid/press-release_MEMO-16-2265_en.htm, Erişim Tarihi: 31.03.2017) üzerinden bunun anlaşılması daha kolay olacaktır. Bu örneğe göre; bir Üye Devlette kurulu bir ilaç firması, umut verici yeni bir ürün geliştirir ve geliştirme masraflarını o Devletteki vergilendirilebilir kazançlarından düşer. Ürün kâr oluşturmaya başlarken, vergisiz bir ülkeye taşınır ve patent başvurusu orada yapılır. Sonuç olarak, bu ürünün fikri mülkiyetine katkı sunan süreçte üretilen tüm değerler,vergi-dışı kalmış olur. Çıkış vergisi ile, ürünün orijinal olarak geliştirildiği Üye Ülke, yurtdışına taşınmadan önce şirketin bu ürünün değeri konusunda vergi koyabilir. Bu tür bir vergilendirme, ekonomik faaliyetin nerede gerçekleştiğine daha çok odaklanmaktadır.

Görüldüğü üzere çıkış vergisi, sermaye hareketliliği üzerinde bir kısıtlama olması nedeniyle tarafsızlık ilkesinden sapmadır. Ancak bu sapmanın haklı nedeni vergiden kaçınmanın önlenmesidir. 
Uluslararası sermaye hareketlerinin vergilendirilmesinde tarafsızık ilkesi bakımından Avrupa Birliği uygulamasında devlet yardımları (state aids) yasağına da değinmek gerekir. Avrupa Birliği'nin İşleyişi Hakkında Antlaşma md.107 devlet yardımları yasağını düzenlemektedir. Bu maddeye göre "Bir Antlaşma'da aksi belirtilmediği sürece, bir Üye Devlet tarafından verilen herhangi bir yardım veya Devlet kaynaklarının herhangi bir avantaj, belirli teşebbüsleri lehte destekleyen, rekabeti bozan veya tehdit eden herhangi bir biçimde ticaretietkileyecek şekilde tasarruf eden Üye Devletler, iç pazarla uyumlu değildir." Madde 107/1 anlamı çerçevesindeki bir avantaj, bir teşebbüsün normal piyasa koşulları altında, yani Devlet müdahalesi olmadan elde edemeyeceği herhangi bir ekonomik fayda anlamına gelir (Draft Commission Notice on the notion of State aid pursuant to Article 107(1) TFEU) . Bu maddeden anlaşıldığı üzere devlet yardımı yasağının uygulanabilmesi için 4 koşul gereklidir. Bu koşullar şu şekilde sıralanabilir:

- Devlet veya Devlet kaynaklarından piyasaya (örn. Hibeler, faiz ve vergi indirimleri, vergi anlaşmaları vb.) finansal müdahale yapılmalıdır.

- Bu müdahale, alıcı üzerinde bir avantaj getirmelidir,

- Müdahale, rekabeti bozacak veya tehdit edecek nitelikte olmalıdır;

- Müdahale, Üye Devletler arasındaki ticareti etkileyebilmelidir.

Görüldüğü gibi maddede belirtilen rekabeti bozma/ticareti etkileme sebeplerinin yasak için koşul oluşturması, vergi tarafsızlığı ilkesinin de korumayı amaçladığı değerlerle uyum içindedir. Bu nedenle devlet yardımlarının yasaklanma rejimi, tarafsızlık ilkesine de hizmet edecektir.

Konumuz bakımından Avrupa İnsan Hakları Sözleşmesi uygulamasına da göz atmakta fayda vardır. Çünkü vergi ile ilgili birçok mesele, müdahale ettiği alanlar ve haklar göz önünde bulundurulduğunda bir insan hakları meselesidir. $A B$ hukuku ve AiHS -AB'nin bütün üyeleri AiHS'e katılım gösterdiği için- yakın bir ilişki içindedir. AiHS uygulamasında ayrımcılık yasağı, muhakkak bir hak ile bağlantılı olarak ele alınır ${ }^{6}$. Nitekim AïS Madde 14 Ayrımcılık yasağı: "Bu Sözleşme'de tanınan hak ve özgürlüklerden yararlanma, cinsiyet, ırk, renk, dil, din, siyasal veya diğer kanaatler, ulusal veya toplumsal köken, ulusal bir azınlığa aidiyet, servet, doğum başta olmak üzere herhangi başka bir duruma dayalı hiçbir ayrımcılık gözetilmeksizin sağlanmalıdır"(vurgu bize aittir) şeklindedir. Konumuz bakımından bağlantılı hak, mülkiyet hakkı olarak karşımıza çıkar. AiHS'e ek 1 nolu protokol madde 1'de mülkiyet

\footnotetext{
${ }^{6}$ Ancak belirtmek gerekir ki, protokol 12, bu kapsamı genişletmiştir. Protokol No.12'nin Sözleşme sistemine dahil etmeyi hedeflediği "Genel ayrımcılık yasağı" kenar başlıklı 1. maddesine göre “(1)Yasayla tanınan herhangi bir haktan yararlanma, cinsiyet, ırk, renk, dil, din, siyasal ya da başka görüş; ulusal ya da toplumsal köken, bir ulusal azınlığa mensup olma, mülkiyet, doğum ya da diğer statüler gibi herhangi bir temelde ayrımcılık olmaksızın güvence altına alınacaktır. (2) Hiç kimse, herhangi bir kamu makamı tarafından 1. fıkrada belirtilen herhangi bir temelde ayrımcılığa tabi tutulmayacaktır." Türkiye'nin bu protokolü onaylamadığını belirtelim.
} 
hakkının sınırlama ölçütü kamu yararı ve genel yarar olarak belirlenmiştir ${ }^{7}$. Genel yarar ölçütü kontrol niteliğinde müdahaleleri(Gemalmaz, 2009;474) düzenleyen ikinci fıkrada geçer. Vergileri de içeren bu fıkra hükmü, konumuz bakımından bizi asıl ilgilendiren düzenlemedir. Devletlerin mülkiyet hakkı ile bağlantılı ayrımcılık yasağı uygulamasında ölçüt belirleme/ kamu yararının ve/ veya genel yararın bulunup bulunmadığını belirleme konusunda mutlak bir takdir marjı (wide margin of appreciation) vardır ${ }^{8}$. Kamu yararı ile meşru amaç ölçütünün sağlanıp sağlanmadığı değerlendirmesi yapıldıktan sonra ise, ölçülülük kapsamında bir değerlendirme yapılması gerekir. Burada da ayrımcı uygulamaya sebep olan araç ile kamu yararı arasında adil bir dengenin gözetilip gözetilmediğine bakılır (Gemalmaz, 2009; 522).

\subsection{Türkiye'de Mevcut Durum}

Türkiye Cumhuriyeti Devleti'nin uygulamaları ile sermaye ihraç tarafsızlığı arasındaki bağlantıya bakacak olursak şu tespitlerde bulunmak mümkündür: Gelir üzerinden anlınan vergiler konusunda Türk Vergi Sistemi kural olarak ikamet ilkesini benimser. Bu bağlamda yerel yatırımcının geliri elde ettiği yere bakmaksızın vergilendirir. Nitekim, tam mükellefler gerçek kişilerin hangi ülkede olursa olsun, elde etikleri bütün gelirler toplanarak vergilendirilmektedir. Bu itibarla Gelir Vergisi Kanunu'nun 3'üncü maddesi, tam mükellefiyette ikametgah esasını benimsemektedir. Buna karşılık dar mükellef gerçek kişilerin yalnız Türkiye'de elde ettikleri kazanç ve iratlar üzerinden vergilendirilmesini kabul etmektedir. Bu anlamda Gelir Vergisi Kanunu, dar mükellefiyetle sınırlı olarak kaynak ilkesine de yer vermektedir. Kurumlar Vergisi Kanunu'nun (KVK) 3. maddesi ise, kanuni veya iş merkezi Türkiye'de bulunan kurumları tam mükellef olarak değerlendirmektedir. Bu durumda, tam mükellef olarak nitelendirilen kurumlar, hem yurt içi hem de yurt dışında elde ettikleri kazançlarının tamamı üzerinden Türkiye'de vergilendirilmekte, bu bağlamda kurumlar vergisi sisteminin de kural olarak ikamet ilkesini benimsediği görülmektedir. Gerek ikamet ilkesi gerek istisna ve indirim yöntemi ile çifte vergilendirmenin önlenmesi araçları sermaye ihraç tarafsızlığını sağlar.

Türkiye Cumhuriyeti Devleti'nin uygulamaları ile sermaye ithal tarafsılığı arasındaki ilişkide ise şu tespitlerde bulunmak mümkündür: Türkiye sermaye yatırımlarının vergilendirilmesinde ikamet esasını benimseyerek kaynak ilkesine ve dolayısıyla sermaye ithal tarafsızlığına uygun olmayan bir sistem oluşturmuştur. Ancak

\footnotetext{
${ }^{7}$ MADDE 1 Mülkiyetin korunması: “Her gerçek ve tüzel kişinin mal ve mülk dokunulmazlığına saygı gösterilmesini isteme hakkı vardır. Bir kimse, ancak kamu yararı sebebiyle ve yasada öngörülen koşullara ve uluslararası hukukun genel ilkelerine uygun olarak mal ve mülkünden yoksun bırakılabilir. Yukarıdaki hükümler, devletlerin, mülkiyetin kamu yararına uygun olarak kullanılmasını düzenlemek veya vergilerin ya da başka katkıların veya para cezalarının ödenmesini sağlamak için gerekli gördükleri yasaları uygulama konusunda sahip oldukları hakka halel getirmez." Her ne kadar Türkçe resmi çevirinin iki fıkrasında da kamu yararı ifadesi geçiyorsa da metnin orjinalinde 1. Fıkrada "public interest/ d'utilité publique", ikinci fıkrada ise "general interest/ l'intérêt general" ifadeleri yer almaktadır. Çalışmanın sınırı bakımından bununla ilgili tartışmalar yapılmayacaksa da, bu farklılığa işaret etmekte fayda var.

${ }^{8}$ ECHR, Case of Muratović V. Serbia (Application no. 41698/06), 21/03/2017.
} 
yerli yatırımcı ile yabancı yatırımcı arasındaki ayrımcılığın ortadan kaldırılması konusunda yukarıda ele alınan $O E C D$ ve $A B$ yaklaşımlarını destekleyerek bu ilkeye aykırılı̆̆ın etkileri (örneğin haksız rekabet) hafifletilmektedir.

1982 Türkiye Cumhuriyeti Anayasası düzleminde tarafsızlık ilkesine temel oluşturabilecek düzenlemeler; md.2 hukuk devleti ilkesi, md. 10 eşitlik ilkesi (Herkes, dil, ırk, renk, cinsiyet, siyasi düşünce, felsefi inanç, din, mezhep ve benzeri sebeplerle ayırım gözetilmeksizin kanun önünde eşittir.), md.13 temel hak ve hürriyetlerin sınırlandırılma rejimi ${ }^{9}$ (Temel hak ve hürriyetler, özlerine dokunulmaksızın yalnızca Anayasanın ilgili maddelerinde belirtilen sebeplere bağlı olarak ve ancak kanunla sınırlanabilir. Bu sınırlamalar, Anayasanın sözüne ve ruhuna, demokratik toplum düzeninin ve lâik Cumhuriyetin gereklerine ve ölçülülük ilkesine aykırı olamaz.) ve md.35 mülkiyet hakkı olarak sıralanabilir. Ayrıca, konuyla bağlantılı olarak Türkiye'nin taraf olduğu uluslararası anlaşmaların varlığı nedeniyle md. 90/ 5 de (Usulüne göre yürürlüğe konulmuş milletlerarası andlaşmalar kanun hükmündedir.) ilkemize temel oluşturabilecek normatif değerlerden biridir. Yine Anayasa'da dağınık bir şekilde yer alan devletin iktisadi ve sosyal ödevleri (ör. md. 167) ve bu ödevlerin sınırı (md. 65) konumuz ile ilişkili anayasal düzenlemelerdir.

Eşitlik ilkesinin tarafsızlığın temelinde yatan iki düşünceden biri olduğunu daha önce belirtmiştik. Bu kapsamda uluslararası sermaye yatırımlarının vergilendirmesinde tarafsızlık ilkesini 1982 Anayasasında yer alan eşitlik ilkesi çerçevesinde değerlendirmek mümkündür. Anayasa Mahkemesi, Anayasada yer alan eşitlik ilkesinden sapma durumlarında haklı nedenin varlığına göre bir değerlendirme yapmaktadır. Nitekim AYM vermiş olduğu kararlarda Anayasada öngörülen eşitliğin mutlak anlamda bir eşitlik olmayıp, ortada haklı nedenlerin bulunması halinde, farklı uygulamalara imkân veren bir ilke olduğunu dile getirmektedir (Bkz. AYM, 11.12.1986 Tarih ve E.1985/11, K.1986/29 Sayılı Karar, kaynak). Yine Anayasa Mahkemesi aynı hukuksal durumlar aynı, ayrı hukuksal durumlar farklı kurallara bağlı tutulursa Anayasa'da öngörülen eşitlik ilkesi zedelemeyeceğini sıklıkla dile getirmektedir(Örnek olsun; AYM, 2.11.2016 Tarih ve E.2015/61, K.2016/172 Sayılı ve AYM,28.1.2016 Tarih ve E.2014/92, K. 2016/6 Sayılı Kararlar, kaynak)

Temel hak ve hürriyetler çerçevesinde konuyu ele aldığımzıda; uluslararası sermayenin vergilendirilmesinde karşımıza çıkacak olan tüm kısıtlamaları ve/ veya ayrımcı uygulamaları temel hak ve özgürlüklerin sınırlandırılması rejimi çerçevesinde düşünmemiz gerekir. Bu nedenle, böyle bir kısıtlamanın ve/ veya ayrımcılığın her şeyden önce ölçülülük ilkesine aykırı olmaması gerekir. Başka bir ifadeyle, sermaye hareketliliği üzerine konacak olan bir vergi; amaca uygun, amaç için gerekli ve amaç ile orantılı olmalıdır (Başaran Yavaşlar, 2009: 187). Sermaye hareketleri üzerine konacak olan kısıtlayıcı düzenlemeler genel olarak ekonomik bir amaç taşırlar. Bu nedenle;

- Getirilen düzenlemenin ekonomik amaç için uygun olması,

\footnotetext{
9 Madde 13'ün vergilendirme alanında uygulanmasına ilişkin ayrıntılı bir çalışma için bkz. Başaran Yavaşlar, 2009: 147-202. İşbu çalışmamızda, konunun ve çakışmanın sınırı bakımından ilgili maddede yer alan koşullardan yalnızca ölçülülük ilkesi üzerinde durulmuştur.
} 
- Hedeflenen ekonomik amacın gerçekleştirilmesi için o düzenlemenin gerekli olması,

- Getirilen düzenleme ile ekonomik amaç arasında bir orantının bulunması,

gerekir. Ancak bu ilkenin uygulanmasında bazı zorluklar olduğu açıktır (Başaran Yavaşlar, 2009: 189). Şöyle ki, uygunluk, gereklilik ve orantılılık tespiti için yasama organının takdir yetkisini denetleyecek olan yargıcın elinde bu denetime uygun normatif bir tespit ölçütü yoktur (Rumpf, 1993: 46-48).

Türk vergi sisteminin sermaye hareketliliği üzerindeki genel tutumu kısıtlamaları kaldırmak şeklindedir. Buna karşın teşvik düzenlemelerine getirilen genel bir yasak bulunmadığı için, teşvikler aracılığıyla eşitlikten ve tarafsızlık ilkesinden sapma durumları ortaya çıkabilmektedir. Nitekim 4875 Sayılı (DYY) Kanunu md. 1 açıkça yabancı yatırımın teşvik edilmesinin bir amaç olduğunu dile getirmektedir. Yine 2011/1 Sayılı Pazar Araştırması ve Pazara Giriş Desteği Hakkında Tebliğ md.5 vd., yerli yatırımcının yurtdışı yatırımını desteklemektedir. Yasakoyucu, ekonomik ve sosyal sebeplerle eşitlik ilkesinden sapma oluşturan düzenlemeler meydana getirebilir (Öncel vd., 2016: 43). Bu sapmaların anayasal bir dayanağı, başka bir deyişle meşruiyetini anayasadan alan haklı bir nedeni var ise, hukuken kabul edilebilirler (Öncel vd., 2016: 43). Sermaye hareketliliği bakımından teşvik yoluyla oluşan eşitlikten sapma durumlarının haklı nedeni olarak Anayasa'da belirtilen nedenler olarak şunlar sıralanabilir;

- Milli ekonominin gerekleri (md. 48/2)

- Sosyal amaçlar(md. 48/2)

- Ekonomik, sosyal ve kültürel kalkınma(md. 166/1)

- Millî tasarrufun ve üretimin artırılması (md. 166/2)

- Fiyatlarda istikrar(md. 166/2)

- Dış ödemelerde denge sağlanması (md. 166/2)

- Toplum yararları ve gerekleri (md. 166/2)

- Kaynakların verimli şekilde kullanılması (md. 166/2)

- Para, kredi, sermaye, mal ve hizmet piyasalarının sağlıklı ve düzenli işlemeleri (md. 167/1)

- Ülke ekonomisinin düzenlenmesi (md. 167/2)

Anılan bu nedenler, Devletin Anayasa ile belirlenen görevlerindendir. Nitekim "Devlet, sosyal ve ekonomik alanlarda Anayasa ile belirlenen görevlerini, bu görevlerin amaçlarına uygunöncelikleri gözeterek malî kaynaklarının yeterliliği ölçüsünde yerine getirir" (AY. md. 65). Devletin anılan ödevleri yerine getirirken sermayeyi bir araç olarak kullanması ve bu nedenle tarafsızlık ilkesinden sapması mümkündür. Ancak tekrara düşmek pahasına belritmek gerekir ki, bunun yapılabilmesi için bir haklı nedenin varlığı ve ölçülülük ilkesinin şartlarının gerçekleşmesi gerekir. 
Türkiye, uluslararası alanda çifte vergilendirmeyi önleme anlaşmalarıyla da mükelleflerin vergi yüklerinin artmasını engelleyici önlemler almaya çalışmaktadır ${ }^{10}$.

\section{Sonuç}

Vergi tarafsızlığı, vergilendirme ilişkisinin tarafları üzerinden yapılacak olan, biri olumlu biri olumsuz olmak üzere iki farklı içerikle ifadesini bulur. Olumlu içerik; Devletin vergi ödevlilerine karşı tarafsız olması gerektiğine işaret eder ve bu anlamda eşitlik ilkesinin bir alt ilkesi olarak değerlendirilir. Olumsuz olan ikinci içerik ise, Devletin oluşturacağı vergi sisteminin mükelleflerin karar alma sürecine etki etmemesi gerektiğine atıf yapar. Bu bağlamda vergi tarafsızlığı ilkesi devletin müdahale alanının daraltılması ve mükellefin seçim özgürlüğü çerçevesinde, özgürlükler hukuku açısından ele alınır. Kısaca vergilendirmede tarafsızlık ilkesi; vergi sisteminin mükellefler arasında ayrım gözetmeyecek ve karar alma sürecinde etkili olmayacak ve her mükellef için aynı şekilde oluşturulacak ve uygulanacak şekilde düzenlenmesini gerektirir.

Mevcut düzenlemelerin bu ilke karşısındaki durumuna gelirsek; OECD uygulamasında yerel yatırımcıya destek veren hüküm yasaklanmış, diğer ayrımcılık türleri ise hoş görülmemelerine rağmen yasaklanmamıştır. Avrupa Birliği ve Türkiye bakımından ise yatııım kısıtlamalarına yol açan hükümler yasak olmasına rağmen teşvik hükümlerini yasaklayan herhangi bir hüküm-AB nezdinde devlet yardımları yasağı haricinde- bulunmamaktadır. Bu durum ülkeler arasında vergi rekabetine yol açacak düzenlemeleri teşvik yoluyla yapmalarına, bunun sonucunda ise ayrımcı bir vergi sistemi oluşturmalarına yol açar.

$\mathrm{Bu}$ düzenlemeler göstermektedir ki uluslararası sermayenin vergilendirilmesinde tarafsızlık ilkesi bir amaçtan ziyade araç konumundadır. Ülkeler, ekonomik konjonktüre göre kendileri için en avantajlı vergi sistemini kurmaktadır. Çünkü mevcut durumda sermaye yatırımcısı sermayesinin en fazla getiri elde edeceği yere yatırım yapmak istemekte ve bu esnada, vergiyi de bir maliyet olarak değerlendirip, vergi sonrası getirisi oranını karar sürecine dahil etmektedir. Devletler de bu nedenle vergiyi uluslararası ekonomik ilişkiler üzerinde etkisi olan bir faktör olarak kullanarak tarafsızlık ilkesinden sapmaktadır. Bu sapmaların hukuka uygun kabul edilebilmeleri için; haklı bir nedene dayanmaları, meşru bir amaç taşımaları ve tutarlı olmaları gerekir. Buna ek olarak ölçülülük ilkesi çerçevesinde bir değerlendirme yapılması da gerekir. Buna göre ise; i) getirilen düzenlemesinin o düzenleme ile hedeflenen amaç için uygun olması, ii) hedeflenen amacın gerçekleştirilmesi için o düzenlemesinin gerekli olması, iii) getirilen düzenleme ile hedeflenen amaç arasında bir orantının bulunması gerekir.

\footnotetext{
${ }^{10}$ Türkiye, 24.06.2017 tarihi itibariyle 82 ayrı ülke ile çifte vergilendirmeyi önleme anlaşması imzalamış; bunlardan bazılarını sonrasında revize etmiştir. Tablo için bkz. http://www.gib.gov.tr/fileadmin/ mevzuatek/uluslararasi_mevzuat/VERGIANLASMALIST.htm (Erişim Tarihi: 24.06.2017)
} 


\section{Kaynakça}

Abbasov, A. (2005). Vergilemenin Uluslararası Doğrudan Sermaye Hareketleri Üzerindeki Etkisi: Türkiye Örneği, Ankara Üniversitesi Sosyal Bilimler Enstitüsü, (Yayınlanmamış Yüksek Lisans Tezi), Ankara.

Avrupa Birliği Bakanlığı Ekonomik ve Mali Politikalar Başkanlığı (2012). Finansal İşlem Vergileri ve Avrupa Birliği Uygulaması, Ankara, Temmuz 2012, http://www.ab.gov.tr/files/EMPB/finansal_islem_vergisi_empb_print_version. pdf (12.04.2017).

Barnard, C. (2010). The Substantive Law of the EU: The Four Freedoms, Oxford University Press, Oxford.

Başaran Yavaşlar, F. (2009). "Vergilendirme Yoluyla Temel Hak ve Özgürlüklere Müdahalede Sınır", Kamu Hukuku, Özel Hukuk ve Ceza Hukuku Alanlarında Kamunun Önderliği ve Bireysel Özerklik Sempozyumu, Ankara, 2009, 147-202.

Bracewell-Milnes, B. (1988). "A Liberal Tax Policy: Tax Neutrality and Freedom of Choice, British Tax Review; Libertarian Alliance, London.

Committee on Finance of United States Congress Senate. (2008). The Concept of Neutrality in Tax Policy: Testimony of Jason Furman Before the US Senate Finance Committee, Hearing on Tax: Fundamentals in Advance of Reform, Washington, pp. 9-51.

Eser, E. (2011). Türkiye'de Teşvik Sistemleri ve Mevcut Sistemin Yapısına Yönelik Öneriler, T.C BaşbakanlıkDevlet Planlama Teşkilatı, İktisadi Sektörler ve Koordinasyon Genel Müdürlüğü (Uzmanlık Tezi), Ankara.

European Commission (2016). "The Anti Tax Avoidance Package - Questions and Answers (Updated)", Brussels, 21 June 2016, http://europa.eu/rapid/pressrelease_MEMO-16-2265_en.htm (12.04.2017).

Gelir İdaresi Başkanlığı (2014). Gelir ve Servet Üzerinden Alınan Vergilere IIlişkin Model Anlaşma (Kısaltılmış Basım).

Gemalmaz, B. (2009). Avrupa Insan Hakları Sözleşmesinde Mülkiyet Hakkı, İstanbul, Beta Yayınevi.

Griffith, R., James H., \& Peter B. (2010). "International Capital Taxation" Dimensions of Tax Design, (Ed.) Mirrless J., Wilthsire, Oxford University Press, pp. 914-996.

Furman, J. (2008). "The Concept of Neutrality in Tax Policy" testimony before the US Senate Finance Committee, hearing on Tax: Fundamentals in Advance of Reform., April 2008.

IMF (2010). Fair And Substantial Contribution by the Financial Sector Final Report For The G-20, Toronto, June 2010. 
Knoll, M. S. (2011)."Reconsidering International Tax Neutrality" , Faculty Scholarship, pp. 99-129.

Mason, R. (2010). "Tax Discrimination and Capital Investment", World Tax Journal, Vol.2 (2),pp. 126-139.

OECD (2007). Tax Policy Studies: Tax Effects on Foreign Direct Investment - No. 17.

OECD/TPA (2003). "Are the Current Treaty Rules for Taxing Business Profits Appropriate for E-Commerce?-Final Report".

Öncel M., Kumrulu A., Çağan N. (2016). Vergi Hukuku, 25. Bası, Ankara, TurhanKitabevi.

Rumpf, C. (1993), "Ölçülülük İlkesi ve Anayasa Yargısındaki İşlevi ve Niteliği”, Anayasa Yargısı, C.10, 1993, 25 vd.

Smith, A. (2014) , Milletlerin Zenginliği, İstanbul, Türkiye İş Bankası Kültür Yayınları, 4. Bası (Çev.: Haldun Derin).

Tobin, J. (1994) "A Tax on International Currency Transactions." Human Development Report,p. $994 \mathrm{ff}$.

Üstün A.\& Özsoy B. (2016). “AB'nin Vergiden Kaçınmayla Mücadele Paketi Türk Yatırımcıları da Etkileyebilir", KPMGvergi, http://www.kpmgvergi.com/Blog/ Pages/FullBlog.aspx?article=593, (12.04.2017).

Vail, M. (2011). Marché intérieur et neutralité de l'impôt direct : la construction fiscale européenne revisitée, Université Panthéon-AssasEcole Doctorale Georges Vedel Droit Public Interne Science Administrative et Science Politique, (Yayımlanmamış Doktora Lisans Tezi), Paris.

Warren Jr, A. C. (2001). "Income Tax Discrimination Against International Commerce", Tax Law Review, Vol. 54, pp. 131- 169.

Weisbach, D. A. (2015). "The Use of Neutralities in International Tax Policy", National Tax journal, Vol. 68(3), pp. 635-652. 